\title{
EXPERIMENTAL AND NUMERICAL STUDIES OF THE CARRYING CAPACITY OF A CIRCULAR ARCH UNDER HYDROSTATIC PRESSURE
}

\author{
${ }^{1}$ Surianinov M.G., Doctor of Science, Professor, \\ sng@ogasa.org.ua, ORCID: 0000-0003-2592-5221 \\ ${ }^{1}$ Neutov S.P., PhD., Assistant Professor, \\ neutov.stepan@gmail.com, ORCID: 0000-0002-0132-124X \\ ${ }^{1}$ Korneieva I.B., PhD., Assistant Professor, \\ korneevairinaborisovna@gmail.com, ORCID: 0000-0002-0104-6938 \\ ${ }^{1}$ Kirichenko D.O., postgraduate, \\ sunnyderypeople123@gmail.com, ORCID: 0000-0002-8484-0925 \\ ${ }^{1}$ Odessa State Academy of Civil Engineering and Architecture \\ 4, Didrikhson street, Odessa, 65029, Ukraine
}

\begin{abstract}
The results of a numerical and experimental study of the bearing capacity of a circular concrete arch loaded with hydrostatic pressure are presented. To implement the specified scheme of loading arches, the authors made a stand that allows you to determine the bearing capacity of models of concrete, reinforced concrete, steel-fiber concrete and wooden arches.

For experiments, a double-hinged arch was made of concrete C16/20. At the same time, samples-cubes with an edge size of $10 \mathrm{~cm}$ were prepared from the same batch, which were tested for compression in accordance with the current regulatory documents.

During the tests, the load was applied in small steps for a detailed study of the arch deformation process. At each stage, the readings of the measuring devices, dial indicators and strain gauges, were recorded. For computer modeling and numerical analysis by the finite element method, the software LIRA-SAPR was used.

It is noted that, despite the widespread use of arched structures made of reinforced concrete, there are still no generalizing conclusions and recommendations for determining their actual bearing capacity and strengthening methods in the domestic literature. During the tests, a breaking load of $600 \mathrm{kN}$ was achieved, that is, the bearing capacity of the arch, determined experimentally, was 0.845 of the value obtained by numerical analysis, although, as a rule, in our experimental studies of other structures, the theoretical value of the bearing capacity turned out to be lower than the actual one. In this case, the destruction occurred in the support part, i.e. at the junction of the support (heel) and the arch, which is explained by the lack of reinforcement of the heel. The results of experimental and numerical studies of a concrete arch indicate that under this loading scheme, almost equal stresses arise in all cross sections of the arch. Obviously, the bearing capacity of the structure can be increased due to the uniform dispersed reinforcement of the arch and reinforcement of the heel with bar reinforcement, which determines the direction of our further research.
\end{abstract}

Keywords: concrete, arch, hydrostatic pressure, bearing capacity, numerical analysis, experiment.

Introduction. The arch is one of the most ancient structural elements. The scope of arches is extremely wide - pavilions, covered markets, hangars, gyms, culverts, tunnels, bridges, domes, underground arched structures, etc. In terms of material consumption, arches are much more profitable than beam and frame systems. In addition, arches are easy to manufacture and install.

In our time, arched structures are most often made of reinforced concrete. Reinforced concrete arches are widely used as truss structures, lintels, in bridge structures, and overlappings for industrial buildings. A distinctive feature of these structures is that, with a properly selected outline, the bending moments occurring in them are small, which corresponds to the specifics of concrete -

Bulletin of Odessa State Academy of Civil Engineering and Architecture, 2020, no. 80, page 50-58 
a material that does not work well in tension. The calculation of reinforced concrete arches, as a rule, is carried out exclusively in an elastic formulation. However, this approach does not take into account real physical laws, structural and technological factors, nonlinearity, inelastic deformation of concrete, the appearance and development of cracks, the joint work of concrete and reinforcement, and many other factors.

Improving the theory of resistance of concrete and reinforced concrete structures, including arched ones, based on the development of new approaches in carrying out theoretical, computer and experimental studies, remains an urgent task. This paper investigates a double-hinged concrete arch, outlined along an arc of a circle, under the action of hydrostatic pressure on it.

Recent researches analysis. The classical theory of calculating arches deals with issues that can be conditionally divided into two areas: 1) determination of forces caused by external influences - stationary loads of various types and directions, movable load, temperature, elastic or inelastic displacements of supports, installation, as well as forces caused by the weight of the superstructure and its participation in the work of the arch; 2) selection of a rational outline of the axis, the size of the lifting boom and the law of change in cross-sections. Both of these areas are reflected in the extensive literature [1-4].

Recently, however, the attention of researchers is increasingly attracted by the strengthening of arches through the use of new materials and new approaches in design, which are based on modern possibilities of computer and experimental modeling [5-8].

Despite the widespread use of arched structures made of reinforced concrete, there are still no generalizing conclusions and recommendations for determining their actual bearing capacity and strengthening methods in the domestic literature. The situation is no better in foreign countries, where many works are devoted to the study of arches, in which the results of numerical and experimental modeling are presented, but, basically, we are talking about the problem of stability [9-12].

The purpose of this work is a numerical and experimental study of the bearing capacity of a circular concrete arch to obtain information on the methods of its subsequent increase by means of rod or dispersed reinforcement.

Materials and methods of research. The double-hinged arch is made of C16/20 concrete. At the same time, samples-cubes with an edge size of $10 \mathrm{~cm}$ were made from the same batch, which were tested for compression according to [13]. To implement real loading schemes for arches, a stand was made that allows you to determine the bearing capacity of models of concrete, reinforced concrete, steel fiber concrete and wooden arches. The load was applied in small steps for a detailed study of the arch deformation process. At each stage, the readings of the measuring devices, dial indicators and strain gauges, were recorded. For computer modeling and numerical analysis by the finite element method, the LIRA-SAPR software program was used.

Research results. The choice of a double-hinged arch for research is explained by the fact that such arches can easily deform due to free rotation in the hinges, and, due to this, there is no significant increase in stresses from temperature effects and settlement of supports in them.

From literary sources it is known that when determining the bearing capacity of arched structures, the loading system was most often used in the form of two symmetrically located concentrated forces $[14,15]$. At the same time, in real conditions, arches, as a rule, are loaded with a distributed load throughout the span $[16,17]$.

The stand we made (Fig. 1) allows us to apply a hydrostatic load to the arch, which acts along the entire span. 

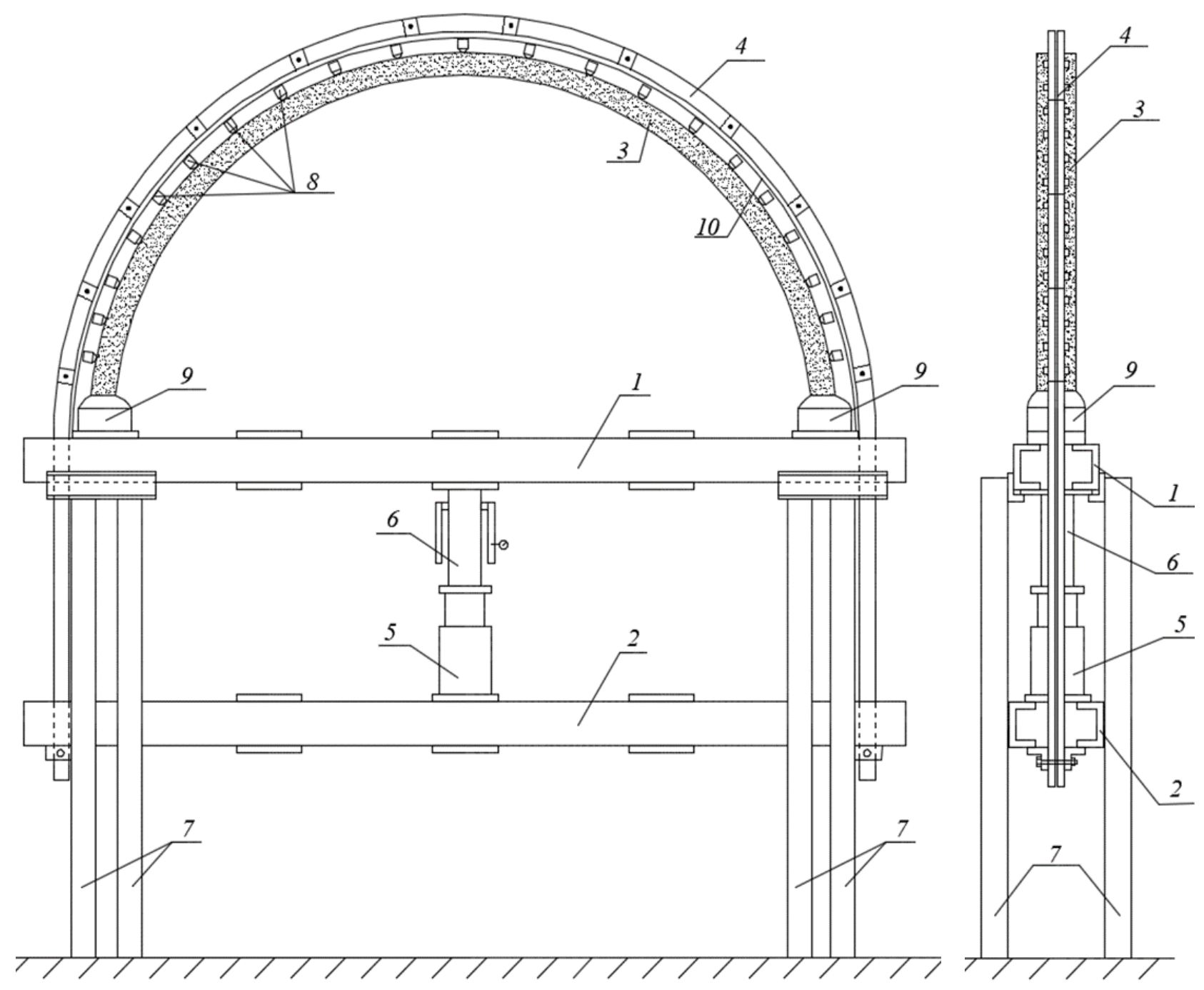

Fig. 1. Test bench: 1 - top loading beam; 2 - lower loading beam suspended by a chain; 3 - concrete arch; 4 - loading chain; 5 - jack; 6 - master dynamometer; 7 - support posts; 8 - rods that transfer the load from the chain to the arch; 9 - support heel; 10 - auxiliary metal strip

The tested arch 3 is installed on the upper load support beam 1, which is supported by four support posts 7. On the side surfaces of the arch, strain gauges are glued, indicators and deflection meters are fixed, with the help of which, in the process of loading, the deformations of the most loaded (dangerous) fibers of the arch material are monitored (Fig. 2).

The arch shown in Fig. 1 is outlined along an arc of a circle (semicircular). Camber of arch $f=100 \mathrm{~cm}$, span $-\ell=200 \mathrm{~cm}$. The cross section is rectangular, $6 \mathrm{~cm}$ high, $12 \mathrm{~cm}$ wide. Arch material - unreinforced concrete of grade C16/20.

A thin metal strip 10 is laid on the upper outer surface of the arch, to which transfer rods 8 are attached every $12 \mathrm{~cm}$ using self-tapping screws. A flexible plate rod 4 is located on the strip 10, which wraps around the arch along the upper belt. The strip 10, due to its low rigidity, takes the shape of the upper belt of the arch and allows the lamellar rod to slide freely over the surface. A flexible lamellar rod is made of metal plates with a cross section of $50 \times 5 \mathrm{~mm}$ and a length of $270 \mathrm{~mm}$. Every $24 \mathrm{~cm}$, four pairs of plates on one side and four on the other are connected alternately with high-strength bolts $\varnothing 16 \mathrm{~mm}$. The total length of the flexible rod is 5 meters. Tensile strength $-222 \mathrm{kN}$. The presence of bolted joints (hinges) allows the flexible plate bar to take the shape of the upper chord of the arch. The second (lower) loading beam 2 is attached to the plate bar 4 . 


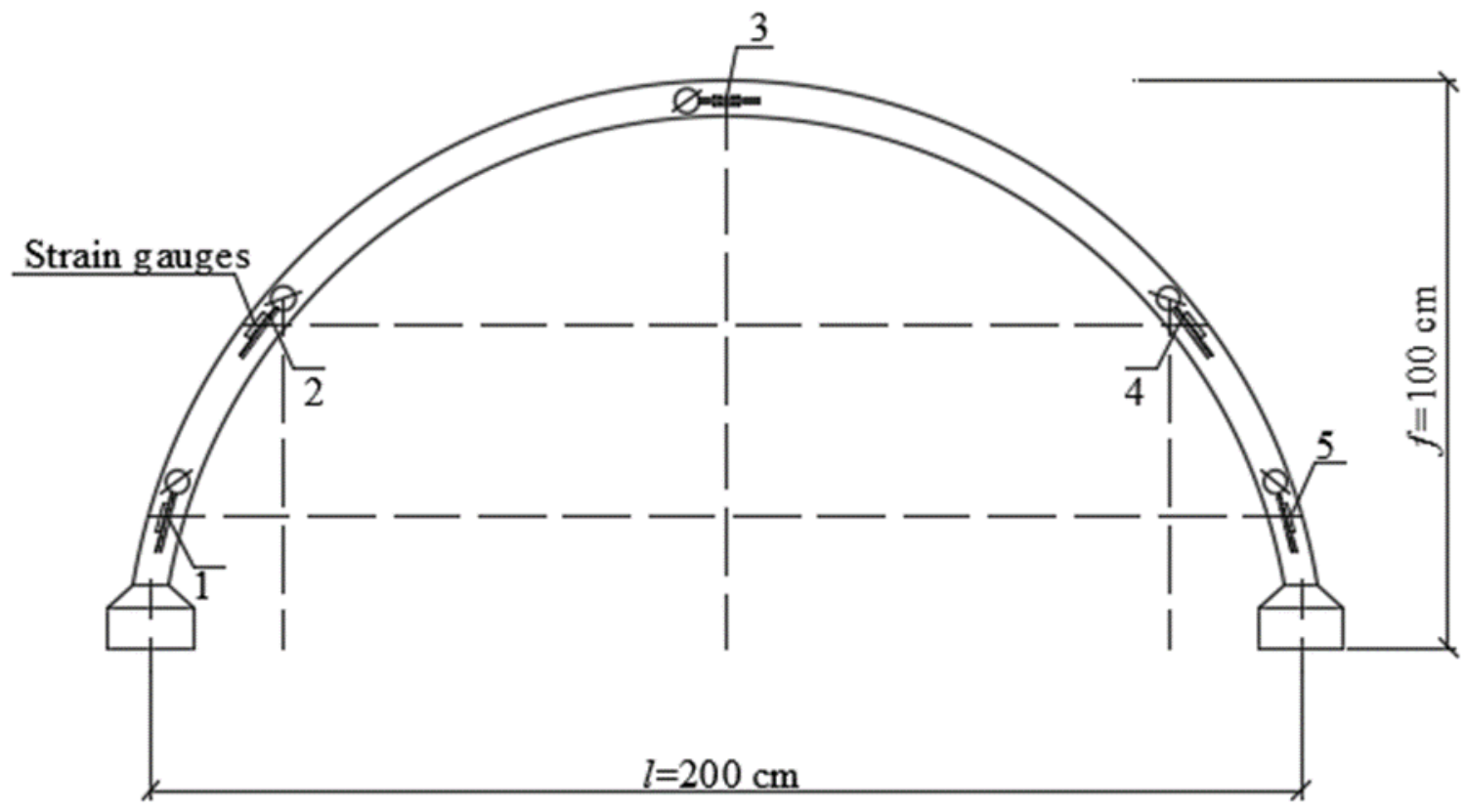

Fig. 2. Strain gauge layout

In the process of loading, the load applied to the lamellar bar, and, therefore, to the arch, as well as the corresponding deformations that occur in the concrete, are recorded. The load is applied in steps. Each stage ends with an exposure duration of 5-8 minutes with fixation of all the necessary parameters. Deformations were measured using strain gauges and dial indicators with a graduation of $0.001 \mathrm{~mm}$, a base of $250 \mathrm{~mm}$. Strain gauges base $-50 \mathrm{~mm}$.

The first and fifth strain gauges (Fig. 2) are located at the supports. The third is in the middle of the span at the level of the «lock», and the second and fourth are symmetrically at the half of the camber of the arch.

In the process of loading, the lower beam 2 with the help of the jack 5 is shifted relative to the upper beam 1, on which the arch 3 rests. The displacement of the lower beam 2 leads to the fact that the flexible lamellar rod, wrapping around the arch, is stretched and a uniformly distributed load (hydrostatic pressure) is transferred to the arch over its entire surface.

The force applied to the beams, and therefore to the plate bar, is controlled using an master dynamometer 6 .

Fig. 3 shows the nature of concrete deformations obtained during loading at the initial stage of the experiment. From the results shown in Fig. 3, it follows that all measuring devices work synchronously and show an almost linear dependence throughout the entire loading process. The latter testifies to the fact that under this loading scheme, practically equal stresses arise in all cross sections of the arch. The loading process ends when the arch loses its ability to resist loading or collapses. The load value corresponding to this moment is taken as the bearing capacity of the arch.

In the investigated concrete arch, destruction occurred in the supporting part, i.e. at the junction of the support (heel) and the arch, with a load of $600 \mathrm{kN}$.

When modeling the arch under study in the LIRA-SAPR software package, the physical and mechanical characteristics were adopted, which were determined experimentally when testing cubic concrete samples:

$$
E=32000 \mathrm{M \Pi а} ; \mu=0,2 ; R_{\text {cube }}=31 \mathrm{M \Pi а} .
$$




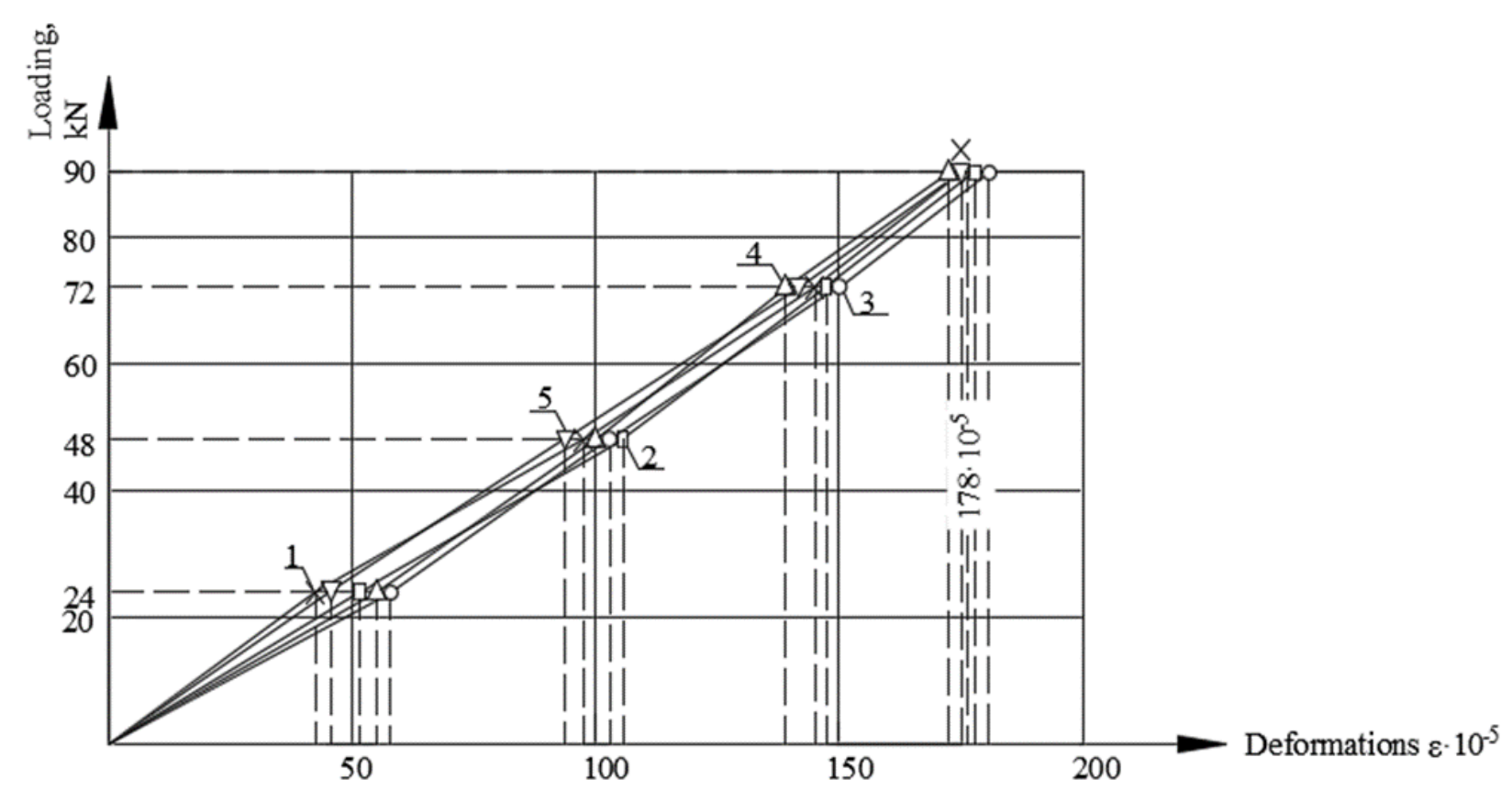

Fig. 3. Relative deformations according to indicators

The calculations were carried out at load values corresponding to the loading steps in experimental studies. Since at a load of $600 \mathrm{kN}$, corresponding to the loss of the bearing capacity of the arch in the experiment, the $G_{x}$ value determined in the LIRA-SAPR software and corresponding to the cubic strength was less than $R_{\text {cube }}=31 \mathrm{M \Pi a}$, the load was increased and brought to $710 \mathrm{kN}$. In this case, the value of $G_{x}$ reached $31.418 \mathrm{MPa}$ (Table 1), which allows us to consider the theoretical value of the bearing capacity of the arch equal to $710 \mathrm{kN}$.

Table 1 - Calculation results in SP LIRA-SAPR with a load of $710 \mathrm{kN}$

\begin{tabular}{|c|c|c|c|c|c|c|}
\hline $\begin{array}{c}\text { № } \\
\text { element }\end{array}$ & $\begin{array}{c}N \\
(\mathrm{kN})\end{array}$ & $\begin{array}{c}M_{y} \\
\left(\mathrm{kN}{ }^{*} \mathrm{~cm}\right)\end{array}$ & $\begin{array}{c}Q_{z} \\
(\mathrm{kN})\end{array}$ & $G_{x} N, \mathrm{MPa}$ & $G_{x} M, \mathrm{MPa}$ & $G_{x}, \mathrm{MPa}$ \\
\hline 1 & 226.209 & 0.000 & 0.066 & 31.418 & 0.000 & 31.418 \\
\hline 2 & 226.209 & 1.080 & 0.085 & 31.418 & 0.050 & 31.418 \\
\hline 3 & 226.209 & 2.468 & 0.057 & 31.418 & 0.114 & 31.532 \\
\hline 4 & 226.209 & 3.401 & 0.065 & 31.418 & 0.157 & 31.575 \\
\hline 5 & 226.209 & 4.464 & 0.053 & 31.418 & 0.207 & 31.625 \\
\hline 6 & 226.209 & 5.320 & 0.055 & 31.418 & 0.246 & 31.664 \\
\hline 7 & 226.209 & 6.209 & 0.040 & 31.418 & 0.287 & 31.705 \\
\hline 8 & 226.209 & 6.856 & 0.039 & 31.418 & 0.317 & 31.735 \\
\hline 9 & 226.209 & 7.485 & 0.019 & 31.418 & 0.347 & 31.764 \\
\hline 10 & 226.209 & 7.789 & 0,011 & 31.418 & 0.361 & 31.778 \\
\hline 11 & 226.209 & 7.975 & 0.000 & 31.418 & 0.369 & 31.787 \\
\hline 12 & 226.209 & 7.975 & -0.011 & 31.418 & 0.369 & 31.787 \\
\hline 13 & 226.209 & 7.789 & -0.019 & 31.418 & 0.361 & 31.778 \\
\hline 14 & 226.209 & 7.485 & -0.039 & 31.418 & 0.347 & 31.764 \\
\hline 15 & 226.209 & 6.856 & -0.040 & 31.418 & 0.317 & 31.735 \\
\hline 16 & 226.209 & 6.209 & -0.055 & 31.418 & 0.287 & 31.705 \\
\hline 17 & 226.209 & 5.320 & -0.053 & 31.418 & 0.246 & 31.664 \\
\hline 18 & 226.209 & 4.464 & -0.065 & 31.418 & 0.207 & 31.625 \\
\hline
\end{tabular}


a)

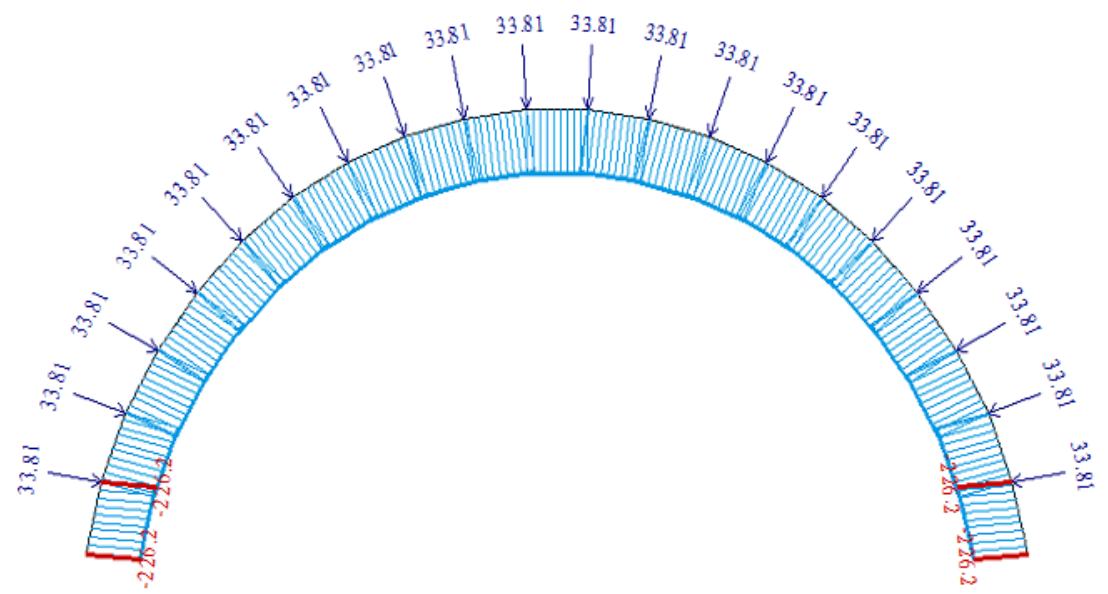

b)

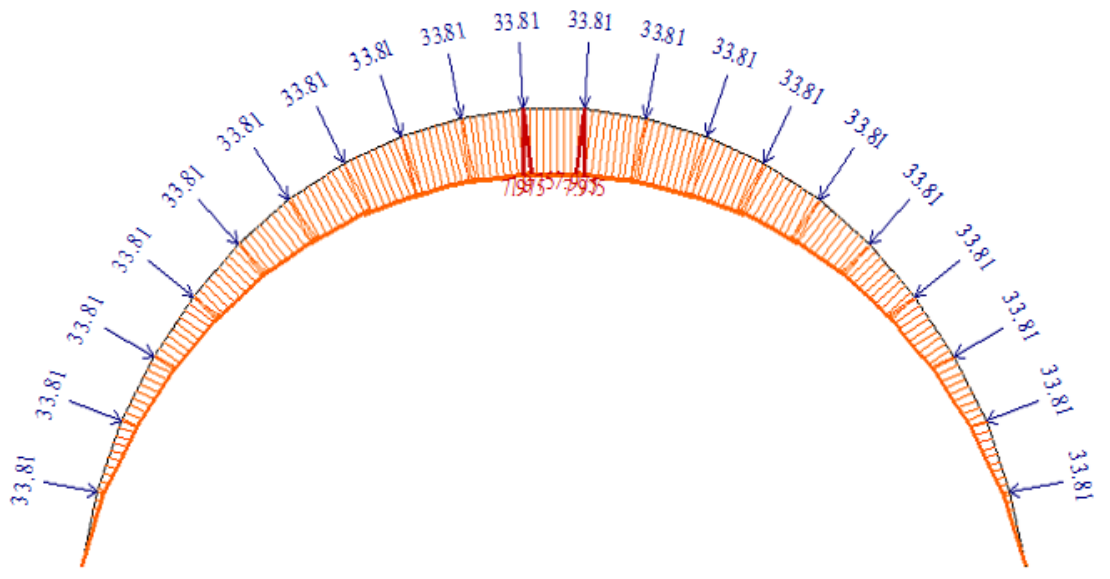

c)

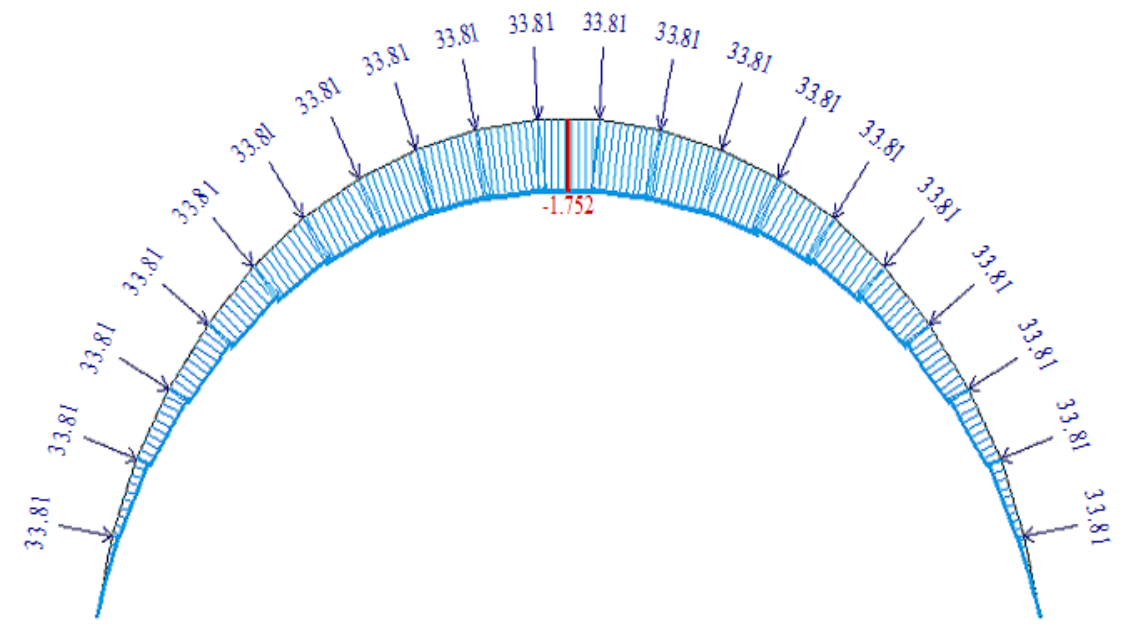

Рис. 4. Результаты расчета при нагрузке 710 кН:

$\mathrm{a}$ - longitudinal forces; $\mathrm{b}$ - bending moments; $\mathrm{c}$ - displacements

Conclusions. During the tests, a breaking load of $600 \mathrm{kN}$ was achieved, that is, the bearing capacity of the arch, determined experimentally, was 0.845 of the value obtained by numerical analysis, although, as a rule, in our experimental studies of other structures, the theoretical value of the bearing capacity turned out to be lower than the actual one. In this case, the destruction occurred in the support part, i.e. at the junction of the support (heel) and the arch, which is explained by the lack of reinforcement of the heel. The results of experimental and numerical studies of a concrete arch indicate that, with this loading scheme, practically equal stresses arise in all cross sections of the arch. Obviously, the bearing capacity of the structure can be increased due to the uniform dispersed reinforcement of the arch and reinforcement of the heel with bar reinforcement, which determines the direction of our further research. 


\section{References}

[1] K.S. Zavriev, Raschet arochnyh mostov. M.: Transzheldorizdat, 1956.

[2] N.K. Snitko, Stroitelnaya mehanika. Vysshaya shkola. Moskva. 1972.

[3] A.F. Smirnov, A.V. Aleksandrov, B.Ya. Lashenikov, N.N. Shaposhnikov, Stroitelnaya mehanika. Sterzhnevye sistemy. M.: Strojizdat, 1981.

[4] I.M. Rabinovich, Osnovy stroitelnoj mehaniki sterzhnevyh sistem. M.: Gosstrojizdat, 1960.

[5] V.V. Pavlov, E.V. Horkov, "Eksperimentalnye issledovaniya raboty ne usilennyh kirpichnyh arok pri smeshenii opor", NIU MGSU, Moskva, pp. 310-315, 2016.

[6] E.V. Horkov, I.T. Mirsayapov, V.V. Pavlov, "Konstruktivno-tehnologicheskie osobennosti vosstanovleniya rabotosposobnosti kamennyh svodchatyh perekrytij zdaniya", Izdatelstvo Mordovskogo universiteta, pp. 177-181, 2019.

[7] Yu.V. Nemirovskij, D.V. Mohovnyov, K.A. Soloveva, "Racionalnoe proektirovanie betonnoj polukrugovoj arki". V 4 t., Izd-vo NGTU, T. 1, pp. 79-83. 2018.

[8] D.V. Anciperovskij, D.A. Zhdanov, S.A. Luzgin, D.I. Ignatushin, A.A. Skurihina, "Racionalnoe proektirovanie zhelezobetonnyh arok", Tehnadzor, no. 12 (109), pp. 176-177, 2015.

[9] Jr., P.S. Harvey, L.N. Virgin, "Coexisting equilibria and stability boundaries of a shallow arch: unilateral displacement-control experiments and theory", Int. J. Solids Struct, 54, 1-11, 2015.

[10] G.M. El-Mahdy, "Parametric study of the structural and in-plane buckling analysis of ogee arches", HBRC Journal, 10, 108-116, 2014.

[11] Jun Yang, Jianting Zhou, Zongshan Wang, Yingxin Zhou and Hong Zhang, "Structural Behavior of Ultrahigh-Performance Fiber-Reinforced Concrete Thin-Walled Arch Subjected to Asymmetric Load", Hindawi Advances in Civil Engineering, pp. 1-12, 2019. https://doi.org/10.1155/2019/9276839.

[12] H. Moradia, A.R. Khaloob, M. Shekarchib, and A. Kazemianb, "Eect of utilizing glass berreinforced polymer on exural strengthening of RC arches", Civil Engineering, 26, pp. 22992309, 2019.

[13] DSTU B.V.2.7-214:2009. Betony. Metody vyznachennya mitsnosti za kontrol'nymy zrazkamy. K.: Minrehionbud Ukrayiny, 2010.

[14] I.K. Dmitriev, "Opredelenie razrushayushih usilij v sterzhne-vantovoj arke", Stroitelnaya mehanika inzhenernyh konstrukcij i sooruzhenij, T.15, no. 3, pp. 243-248, 2019.

[15] N.P. Barbashev, "Raschet zhelezobetonnoj arki v grunte na dejstvie dinamicheskoj nagruzki", Vestnik MTSU, no. 3, pp. 34-43, 2016.

[16] L.R. Mailyan, E.M. Yazyev, A.S. Chepurenko, A.A. Avakov, "Ustojchivost zhelezobetonnoj arki pri polzuchesti", Elektronnyj zhurnal Inzhenernyj vestnik Dona, no. 4, 2015. ivdon.ru/ru/magazine/archive/n4y2015/3378.

[17] I.G. Ovchinnikov, I.I. Ovchinnikov, G.V. Chesnokov, S.A. Feoktistov, "Primenenie zapolnennyh betonom trubchatyh konstrukcij iz fibroarmirovannyh plastikov $\mathrm{v}$ transportnom stroitelstve", Internet-zhurnal «Naukovedenie», no. 4 (23), pp. 103, 2014. 


\title{
ЕКСПЕРИМЕНТАЛЬНІ ТА ЧИСЕЛЬНІ ДОСЛІДЖЕННЯ НЕСУЧОЇ ЗДАТНОСТІ КРУГОВОЇ АРКИ ПРИ ГІДРОСТАТИЧНОМУ ТИСКУ
}

\author{
${ }^{1}$ Сур'янінов М.Г., д.т.н., професор, \\ sng@ogasa.org.ua, ORCID: 0000-0003-2592-5221 \\ ${ }^{1}$ Неутов С.П., к.т.н., доцент, \\ neutov.stepan@gmail.com, ORCID: 0000-0002-0132-124X \\ ${ }^{1}$ Корнеєва I.Б., к.т.н., доцент, \\ korneevairinaborisovna@gmail.com, ORCID: 0000-0002-0104-6938 \\ ${ }^{1}$ Кіріченко Д.О., аспірант, \\ sunnyderypeople123@gmail.com, ORCID: 0000-0002-8484-0925 \\ ${ }^{1}$ Одеська державна академія будівництва та архітектури \\ вул. Дідріхсона, 4, м. Одеса, 65029, Україна
}

Анотація. Представлені результати чисельного та експериментального дослідження несучої здатності кругової бетонної арки, завантаженої гідростатичним тиском. Для реалізації зазначеної схеми завантаження арок авторами виготовлений стенд, що дозволяє визначати несучу здатність моделей бетонних, залізобетонних, сталефібробетонних i дерев'яних арок.

Для експериментів виготовлена двохшарнірна арка з бетону C16/20. Одночасно з цього ж замісу підготовлені зразки-куби з розміром ребра $10 \mathrm{~cm}$, які випробувані на стиск відповідно до чинних нормативних документів.

При випробуваннях навантаження прикладалося невеликими ступенями для детального вивчення процесу деформування арки. На кожному ступені фіксувалися показання вимірювальних приладів, в якості яких використовувалися індикатори годинникового типу i тензодатчики. Для комп'ютерного моделювання і чисельного аналізу методом кінцевих елементів використана програма ПК ЛІРА-САПР.

Відзначено, що, незважаючи на широке поширення аркових конструкцій iз залізобетону, будь-які узагальнюючі висновки і рекомендації щодо визначення їх дійсної несучої здатності і методам посилення у вітчизняній літературі досі відсутні. При випробуваннях було досягнуте руйнівне навантаження $600 \mathrm{\kappa H}$, тобто несуча здатність арки, знайдена експериментально, склала 0,845 від величини, отриманої шляхом чисельного аналізу, хоча, як правило, в проведених нами експериментальних дослідженнях інших конструкцій теоретичне значення несучої здатності виявлялося нижчим за фактичне. При цьому руйнування сталося в опорній частині, тобто в місці з'єднання опори (п'яти) і арки, що пояснюється відсутністю армування п'яти. Результати експериментальних і чисельних досліджень бетонної арки свідчать про те, що при такій схемі навантаження у всіх поперечних перерізах арки виникають практично рівні напруги. Очевидно, що несучу здатність конструкції можна підвищити за рахунок рівномірного дисперсного армування арки і посилення п'яти стрижневою арматурою, що і визначає напрямок наших подальших досліджень.

Ключові слова: бетон, арка, гідростатичний тиск, несуча здатність, чисельний аналіз, експеримент. 


\title{
ЭКСПЕРИМЕНТАЛЬНЫЕ И ЧИСЛЕННЫЕ ИССЛЕДОВАНИЯ НЕСУЩЕЙ СПОСОБНОСТИ КРУГОВОЙ АРКИ ПРИ ГИДРОСТАТИЧЕСКОМ ДАВЛЕНИИ
}

\author{
${ }^{1}$ Сурьянинов Н.Г., д.т.н., профессор, \\ sng@ogasa.org.ua, ORCID: 0000-0003-2592-5221 \\ ${ }^{1}$ Неутов С.Ф., к.Т.Н., доцент, \\ neutov.stepan@gmail.com, ORCID: 0000-0002-0132-124X \\ ${ }^{1}$ Корнеева И.Б., к.т.н., доцент, \\ korneevairinaborisovna@gmail.com, ORCID: 0000-0002-0104-6938 \\ ${ }^{1}$ Кириченко Д.А., аспирант \\ sunnyderypeople123@gmail.com, ORCID: 0000-0002-8484-0925 \\ ${ }^{1}$ Одесская государственная академия строительства и архитектуры \\ ул. Дидрихсона, 4, г. Одесса, 65029, Украина
}

\begin{abstract}
Аннотация. Представлены результаты численного и экспериментального исследования несущей способности круговой бетонной арки, загруженной гидростатическим давлением. Для реализации указанной схемы загружения арок авторами изготовлен стенд, позволяющий определять несущую способность моделей бетонных, железобетонных, сталефибробетонных и деревянных арок.

Для экспериментов изготовлена двухшарнирная арка из бетона С16/20. Одновременно из этого же замеса подготовлены образцы-кубы с размером ребра 10 см, которые испытаны на сжатие в соответствии с действующими нормативными документами.

При испытаниях нагрузка прикладывалась небольшими ступенями для детального изучения процесса деформирования арки. На каждой ступени фиксировались показания измерительных приборов, в качестве которых использовались индикаторы часового типа и тензодатчики. Для компьютерного моделирования и численного анализа методом конечных элементов использована программа ПК ЛИРА-САПР.
\end{abstract}

Отмечено, что, несмотря на широкое распространение арочных конструкций из железобетона, какие-либо обобщающие выводы и рекомендации по определению их действительной несущей способности и методам усиления в отечественной литературе до сих пор отсутствуют. При испытаниях была достигнута разрушающая нагрузка 600 кН, то есть несущая способность арки, определенная экспериментально, составила 0,845 от величины, полученной путем численного анализа, хотя, как правило, в проведенных нами экспериментальных исследованиях других конструкций теоретическое значение несущей способности оказывалось ниже фактического. При этом разрушение произошло в опорной части, т.е. в месте соединения опоры (пяты) и арки, что объясняется отсутствием армирования пяты. Результаты экспериментальных и численных исследований бетонной арки свидетельствуют о том, что при данной схеме нагружения во всех поперечных сечениях арки возникают практически равные напряжения. Очевидно, что несущую способность конструкции можно повысить за счет равномерного дисперсного армирования арки и усиления пяты стержневой арматурой, что и определяет направление наших дальнейших исследований.

Ключевые слова: бетон, арка, гидростатическое давление, несущая способность, численный анализ, эксперимент. 